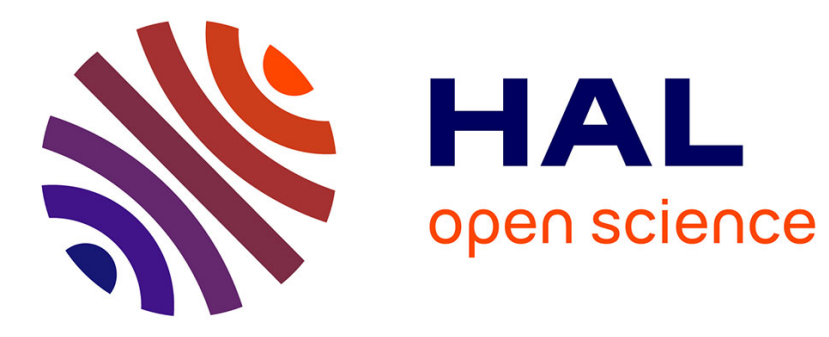

\title{
Physically Based Shading in Theory and Practice
}

Stephen Hill, Stephen Mcauley, Jonathan Dupuy, Yoshiharu Gotanda, Eric

Heitz, Naty Hoffman, Sébastien Lagarde, Anders Langlands, Ian Megibben, Farhez Rayani, et al.

\section{- To cite this version:}

Stephen Hill, Stephen Mcauley, Jonathan Dupuy, Yoshiharu Gotanda, Eric Heitz, et al.. Physically Based Shading in Theory and Practice. ACM SIGGRAPH Courses, Aug 2014, Vancouver, Canada. hal-01066241

\section{HAL Id: hal-01066241 \\ https://inria.hal.science/hal-01066241}

Submitted on 19 Sep 2014

HAL is a multi-disciplinary open access archive for the deposit and dissemination of scientific research documents, whether they are published or not. The documents may come from teaching and research institutions in France or abroad, or from public or private research centers.
L'archive ouverte pluridisciplinaire HAL, est destinée au dépôt et à la diffusion de documents scientifiques de niveau recherche, publiés ou non, émanant des établissements d'enseignement et de recherche français ou étrangers, des laboratoires publics ou privés. 


\title{
Physically Based Shading in Theory and Practice
}

\author{
Stephen Hill \\ Ubisoft Montreal \\ Stephen McAuley \\ Jonathan Dupuy \\ Ubisoft Montreal \\ LIGUM, $^{*}$ LIRIS $^{\dagger}$ \\ Yoshiharu Gotanda \\ Eric Heitz \\ Naty Hoffman \\ Sébastien Lagarde \\ tri-Ace \\ INRIA; CNRS; Univ. Grenoble Alpes \\ Ian Megibben \\ $2 \mathrm{~K}$ \\ EA Frostbite \\ Anders Langlands \\ Solid Angle \\ Pixar Animation Studios \\ Farhez Rayani \\ Pixar Animation Studios \\ Charles de Rousiers \\ EA Frostbite
}

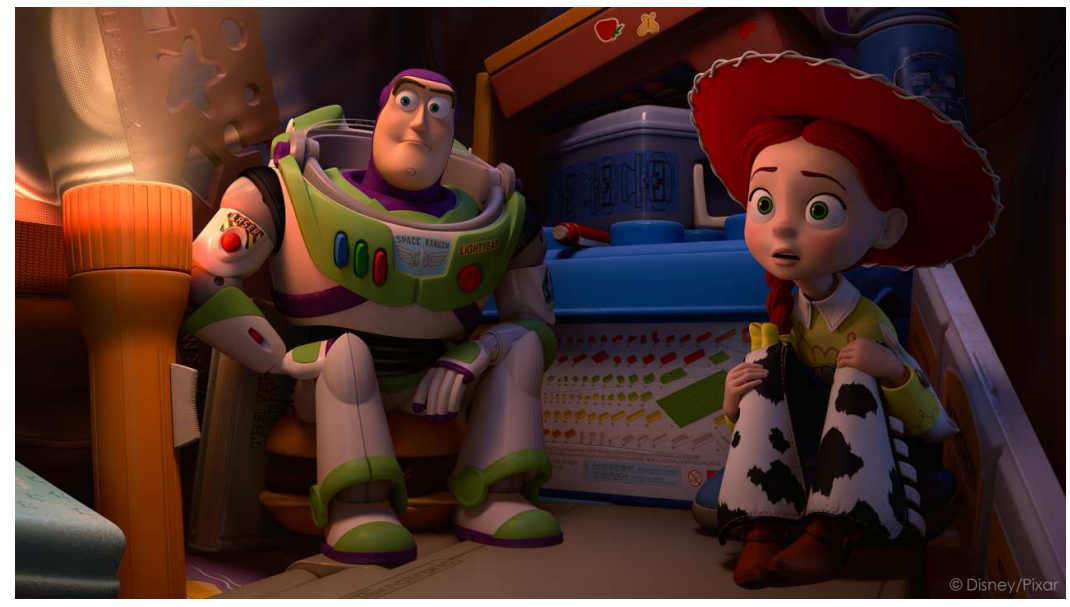

\section{Abstract}

Physically based shading is transforming the way we approach production rendering, and simplifying the lives of artists in the process. By adhering to physically based, energy-conserving models, one can easily create realistic materials that maintain their properties under a variety of lighting conditions. In contrast, traditional ad hoc models have required extensive tweaking to achieve the same result. Building upon previous incarnations of the course, we present further research and practical advice on the subject, from film and game production.

LEVEL OF DifFICULTY: Intermediate

INTENDED AUDIENCE: Practitioners from videogame, CG animation, and VFX fields, plus researchers interested in shading models.

PREREQUisites: A basic understanding of computer graphics, lighting and shading models.

\section{Schedule}

Physics And Math of Shading (Hoffman)

A speed-of-light tour of the physics of light-matter interaction and how it is expressed in simple shading models.

\section{UndERSTANDING THE MASKING-Shadowing Function (Heitz)}

Eric unmasks and intuitively explains this oft-misunderstood microfacet function, leading to fresh insights and results.

\section{Antialiasing Physically Based Shading with LEADR MAPPING (Dupuy)}

*LIGUM, Dept. I.R.O., Université de Montréal

${ }^{\dagger}$ Université de Lyon, CNRS
Jonathan describes the tools necessary to robustly filter microfacet BRDFs in the presence of normal or displacement mapping.

Designing Reflectance Models for New Consoles (Gotanda)

This talk covers improved real-time shading models, afforded by the latest wave of videogame hardware.

Break

Moving Frostbite to PBR (Lagarde and de Rousiers) Séb and Charles explain how the Frostbite team (and multiple productions) made a smooth switch to physically based rendering, along with new research developments.

Physically Based Shader Design IN ARnold (Langlands) All about the design of alShaders, an open source library of production shaders for Arnold.

ART Direction Within PIXAR's Physically Based LIGHTING SYSTEM (Megibben and Rayani)

Hear how Pixar transitioned to a new lighting system, from an art production perspective.

\section{Course Website}

All course materials (presentations and notes) can be found at: http://selfshadow.com/publications/s2014-shading-course

\section{References}

McAuley, Hill, H. L. K. N. P. A. M. H. V, 2013. Physically based shading in theory and practice. ACM SIGGRAPH 2013, July. 